\title{
Vigilantes and the State: Understanding Violence through a Security Assemblages Approach
}

\author{
Rebecca Tapscott
}

\begin{abstract}
The notion that states pursue a monopoly over the use of force rings increasingly hollow. From vigilantes that patrol the United States' southern border, to thugs for hire in China, states are characterized by non-state violent actors. These trends are more pronounced in comparatively lower-capacity states. Employing the concept of "security assemblages," I propose that it is crucial to consider historically embedded relations among violent actors and institutions in order to understand their socio-political role and implications for state authority. This approach offers three insights: first, in low-capacity states, violence is not zero-sum. Rather, it is assembled among diverse actors, which each have historically embedded comparative advantages. Second, therefore, state efforts to monopolize violence should be taken as an empirical question rather than an assumption grounding analysis. Third, relationships between violent actors occur in thick institutional environments, meaning that violent actors, including state actors and institutions, often must act under significant constraints. To illustrate these points, I conduct a mixed-methods nested study of vigilantes in Uganda, finding that vigilantes are more common where other authorities are present, and are more helpful when other authorities are also more helpful. Focusing on dynamics between vigilantes and police, I pinpoint their historically distinct roles: the police were established as a colonial-era institution to suppress political dissent, while vigilantes have long been socially embedded actors tasked with everyday security provision. Thus, in this case, police and vigilantes are not substitutes; instead they play distinct and complementary roles.
\end{abstract}

\footnotetext{
T
} he notion that states pursue a monopoly over the use of force rings increasingly hollow. Even states with the greatest violent capacity worldwide offer evidence to the contrary. In the United States, a strong tradition of militias and vigilantism casts a shadow over the state's history from the frontiers of the "Wild West" to its Southern border with Mexico, and from the $\mathrm{Ku}$

A list of permanent links to Supplemental Materials provided by the author precedes the References section.

Data replication sets are available in Harvard Dataverse at: https://doi.org/10.7910/DVN/ONU9NB

Rebecca Tapscott 1 is an Ambizione Fellow and Lecturer at the
Albert Hirschman Centre on Democracy at the Graduate
Institute in Geneva, and a visiting fellow at the Firoz Lalji
Centre on Africa at the London School of Economics and the
Department Politics and International Relations at the Uni-
versity of Edinburgh (Rebecca. Tapscott@graduateinstitute.ch).
She is the author of Arbitrary States: Social Control and
Modern Authoritarianism in Museveni's Uganda (Oxford
University Press, 2021).

Klux Klan to Kenosha. In Russia, criminal fraternities, racketeering gangs, and war veterans operate as violent entrepreneurs (Volkov 2002). In China, local governments employ "thugs" to enforce unpopular policies while evading responsibility (Ong 2018). These dynamics are further pronounced in states with comparatively limited capacity-countries such as Brazil, Indonesia, and South Africa are beset by vigilantism, private security companies, gangs, and parastatal security groups (Willis 2015; Jaffrey 2020; Marks, Shearing, and Wood 2009).

Especially in low-capacity states-where governments are neither meaningfully absent nor have the ability to convincingly assert that they are the only game in towngovernments may have no choice but to collaborate with a diverse range of informal and non-state violent actors (Ahram 2011; Carey, Mitchell, and Lowe 2013). Scholars seeking to understand how the presence of non-state violent actors impacts on state authority and security outcomes have widely recognized that their informal and fluid nature requires contextualized inquiry focused on the quality of violence that actors can deploy, rather than the quantity (Mukhopadhyay 2014; Reno 2011; Staniland 2017).

I extend these insights to propose that, especially in lowcapacity states, it is crucial to examine the quality of Open Access a creativecommons.org/licenses/by-nc-sa/4.0/), which permits non-commercial re-use, distribution, and reproduction in any medium, provided the same Creative Commons licence is included and the original work is properly cited. The written permission of Cambridge University Press must be obtained for commercial re-use. 
violence from the vantage point of historically embedded relations among violent actors and institutions. By lowcapacity states, I mean those "incapable of fulfilling the fundamental tasks of modern states-monopolizing violence in a given territory and providing basic services to their citizens" (Chowdhury 2018, 2). In contrast to highcapacity states, which can choose whether or not to tolerate violence organized outside the state, low-capacity states often have fewer options for whom to collaborate with and how. In such contexts, violent actors' particular and historical characteristics shape their comparative advantage in regard to the type of violence they use, how, and to what ends, with enduring implications for state authority and the provision of security. Take, for example, the British colonial practice of forming ethnicized militaries that continues to have destabilizing effects today in countries ranging from Myanmar to Zambia (Harkness 2016; Ray 2013).

My intervention offers three contributions to conceptualizing the so-called monopoly on the use of force in lowcapacity states: first, control over violence should not be seen as zero-sum. Said differently, in these contexts, when non-state actors claim to use violence authoritatively, it does not necessarily undermine or contradict the state's claim to do so-sometimes this can actually reinforce state authority. It is therefore helpful to view the organization of violence in low-capacity states as assembled among diverse actors, each with their own historically embedded comparative advantages. Second, such states do not necessarily seek to maximize control over violence, but instead selectively prioritize spaces, sectors, and populations of interest. Third, these decisions occur in already thick institutional environments, meaning that violent actors, including the institutions of the state, are often constrained in terms of who they work with and how.

To demonstrate these points, I examine the relationship between state and non-state violent actors in Uganda, a state with comparatively limited institutional capacity. Focusing on the relationship between vigilantes and the police, the findings show that vigilantes are more common where other public authorities are present, and they are seen as more helpful when these other authorities are also more helpful. ${ }^{1}$ This is therefore a case where the presence and effectiveness of state and non-state violent actors appear to support and even reinforce one another, rather than to undermine or substitute for each other. This complementary dynamic is contingent: whether or not vigilantes support or undermine state authorities (and vice versa) is a product of historically embedded relations, and is therefore a matter for empirical inquiry.

Employing a nested study design that iterates between qualitative and quantitative research and analysis, I unpick the discrete and historically embedded roles played by the police and vigilantes that enable the seemingly counterintuitive dynamics observed in the Ugandan case. In brief, the institution of the Uganda police derives from British colonial intervention, and is structured to help the state control society by repressing collective action and political claim-making. Vigilantes, in contrast, are an outgrowth of long-standing societal responses to local insecurities, and have evolved into a comparatively fragile and locally embedded institution squeezed between the state's security apparatuses and local social orders. Vigilantes are often tasked with managing day-to-day security concerns of ordinary people and addressing low-level crimes; the police focus on high-level crimes and regime maintenance. Vigilantes can also function as an intermediary between the police - seen as a foot-soldier of the repressive state—and society, both helping the police better target local interventions and using the institution of the police to remove "bad elements" from the community.

To elucidate these points, I work with the concept of security assemblages, which is one of several approaches recently advanced to study violence as qualitative and relational. An assemblages approach studies the co-functioning of multiple, contingent, and heterogenous elements, decentering the state/non-state binary to ask: what modes of coercion are available to different actors, how are they complementary or contradictory, and what type of security environment does the "assemblage" collectively produce (Abrahamsen and Williams 2010; Higate and Utas 2017; Müller 2015)? Analytically, an assemblages approach places state institutions on equal footing to non-state actors; their position and importance in a security assemblage must be determined empirically. This framework does not make a normative claim as to whether assemblages improve or worsen security; assemblages can be coherent or fragmented with case-specific security outcomes.

I first examine scholarship on vigilantism to show how conceptions of state control over violence have evolved from a concern with violence as quantitative and zero-sum to a view of violence as qualitative and relational. Vigilantes offer a valuable window into these relational dynamics because they sit at the boundary between presumed binaries like state/non-state; licit/illicit; and constructive/ corrosive (Lund 2006). As a result, they can reveal the nature of a state's control over violence that might otherwise be taken for granted. After discussing the study's methods, I use qualitative findings to outline the mechanisms by which police and vigilantes reinforce each other in this context. Quantitative analysis then shows how these dynamics aggregate to produce particular security outcomes. I discuss these findings and conclude by highlighting how conceptualizing violence as additive, rather than zero-sum, helps us to disentangle the discrete and historically contingent roles played by different violent actors, thereby nuancing assessments of how non-state violent actors impact on state authority and security outcomes in low-capacity states. 


\section{Vigilantes and the "Monopoly on Violence"}

The notion that states pursue exclusive control over violence has undergirded much political science scholarship. As argued by sub-fields including historical and new institutionalist scholars, state formation is premised on continual efforts by violent actors to expand control over coercion to minimize the costs of resource extraction. This could be achieved through direct control over coercion, or indirectly by outsourcing to violent groups (North, Wallis, and Weingast 2009; Olson 2000; Tilly 1992). However, in practice the "monopoly on violence" rarely fits the practices of modern states, which instead share violence with a panoply of non-state and para-state actors (Ahram 2011). As noted by Tuğal, "None of this means that the state is getting weaker, but its strengths and weaknesses are being blended in quite novel ways" (Tuğal 2017, 79). These dynamics are particularly pronounced in the world's lower-capacity states, which are unable to eliminate or control non-state organized violence within their territory, and as a result are typified by highly fragmented security environments (Ahram 2011, Chowdhury 2018). In such contexts, vigilantism has often been studied as a window into the state's control over violence, offering insights on issues ranging from state sovereignty and state consolidation to democratic governance (Abrahams 1998; Buur and Jensen 2004; Smith 2019).

For scholarship premised on the view that states seek to control violence, the mere presence of non-state violent actors necessarily detracts from state authority. In this view, vigilantes are a response to a real or perceived security gap left by an absent or ineffective state. For instance, Abrahams terms vigilantism a "frontier phenomenon ... where [state] power is significantly diluted or resisted" (Abrahams 1998, 24), while Johnston specifies that vigilantism occurs when private citizens act "without the state's authority or support" (Johnston 1996, 226). A related argument sees vigilantism as a response to an impotent or indifferent state; a "cheap form of law enforcement" catalyzed by the decentralization and privatization of policing (Pratten and Sen 2008, 3). This argument therefore necessarily interprets vigilantism as a substitute for the state, implying a zero-sum view of security.

Others have emphasized the entangled and at times co-constituting nature of vigilantism and state authority. For instance, state actors sometimes leverage vigilante groups to carry out work they are unable-or unwilling - to do. Meagher (2007) details how in Nigeria, state actors "hijacked" vigilante groups to promote their own political interests; Cooper-Knock and Owen (2014) document police officers in Nigeria and South Africa who go off-book to pursue justice, engaging in a kind of "vigilante policing." Mutahi explains how Kenyan vigilantes reflect an economy of informal security, including "a complex pattern of overlapping agencies providing security, depending on the time of day, social status of the person involved and the economic activity they are engaged in" $(2011,12)$. These studies show how interactions between state agents and vigilantes produce qualitatively particular outcomes that cannot be boiled down to "more" or "less" security, much less a contest to control violence as an exhaustible resource.

A burgeoning scholarship offers new frameworks that account for the multiplicity of violent actors in any given setting. For instance, concepts such as "armed politics" (Staniland 2017) and the "security arena" (Glawion 2020) help "systematically study the fluidity and heterogeneity of state-armed group relationships," focusing on long-term dynamics rather than violent episodes, and moving from a siloed view of different types of violent actors to a relational perspective (Staniland 2017, 459). Still, these approaches share the assumption that violent actors behave primarily as competitors struggling to maximize control over the use of force.

I employ the concept of "security assemblages" to extend this scholarship. Analytically, security assemblages are agnostic to the goals of violent actors, as well as to the position of the state in the assemblage. Instead, they emphasize historically embedded relations among violent actors, which I liken to comparative advantages. Following in the footsteps of other scholars, I use the term nonnormatively to describe relationships among a given constellation of violent actors (Abrahamsen and Williams 2010; Higate and Utas 2017). Extending the insight that violence is qualitative and relational, I emphasize that control of violence is not necessarily zero-sum. Instead of articulating state efforts to control violence as an assumption grounding analysis, I articulate it as a question to be observed empirically. A security assemblages approach can help answer this empirical question, uncovering why violent actors might seek to dominate particular geographic regions, sectors, or kinds of violence, while ceding control or collaborating in other areas.

The dynamics of any given assemblage vary, producing case-specific security outcomes with historically embedded institutional legacies. For instance, Heald traces vigilante groups - called sungusungu — which emerged in different areas of Tanzania between the 1980s and 1990s in response to cattle raiding and insecurity. While the state's political and administrative wings favored vigilantes as a way to outsource security provision, the judiciary and police saw vigilantes as a threat to their authority and sought to eliminate them by applying the full force of the law to their illegal activities. She concludes that "the sungusungu have come to operate in a distinctive space; co-opting government, and, in turn, co-opted by it" (2006, 281). In Kenya, Rasmussen traces how successive regimes employed tactics of divide-and-rule, and mobilized ethnic 
militias and youth gangs to carry out extralegal state violence, thereby creating an increasingly fragmented security sector. In this context, vigilantes called Mungiki emerged as security providers, as guns for hire, and as security threats, becoming integral to state management of violence. For instance, in return for supporting key elites, the Mungiki were permitted to take over lucrative taxi routes without police interference (Rasmussen 2017, 132).

Vigilantism therefore has a complex relationship to the state and the state's ability to manage violence. Just as nonstate violent actors can be a response to (and further cause of) state absence, fragility, or failure, they can equally be additive to an already thick security and governance landscape. Especially in low-capacity states, these dynamics do not necessarily detract from state authority-an authority that could never have been persuasively premised on control over violence within the territory. In such contexts, a historically informed analysis of violent actors can help surface their comparative advantages, and further reveal how governments - themselves violent actors in the assemblage-may be limited in terms of who they can work with and how.

Drawing on original empirical data from Uganda, the following sections examine the role of vigilantes and the police as a window into how violence is assembled in the country. The findings show that the Ugandan state maintains control over violence that allows it to manage the population (often by repression), while relying on other actors like vigilantes to handle day-to-day security concerns. Vigilantes themselves are not explicitly political actors, but instead complement the regime's focus on precluding social and political mobilization. This shows that the Ugandan state sustains a fragmented security assemblage that allows the ruling regime to maintain control while appearing more present and consolidated than it actually is (Tapscott 2021).

\section{Methods: Case, Data, and Measurement}

\section{Case Selection: Northern Uganda}

Northern Uganda is a useful case to examine how vigilantes impact the state's control over violence. First, vigilantism is extremely common in northern Uganda, with nearly $90 \%$ of respondents reporting that vigilantes are present in their communities. Second, the country has a history of the presence of informal local security actors, which have had complex and changing alliances with state authorities. Finally, during the period of research, the Ugandan government was still solidifying control over the recently post-conflict north, and had an irregular presence, thereby offering variation to probe the role of vigilantes in the security and governance landscape.

In addition to vigilantes, Uganda's security landscape is replete with irregular violent actors. The now-ruling National Resistance Movement (NRM) regime, led by
Yoweri Museveni, took power in 1986 by rebel insurgency. Early in its rule, the NRM formed Local Defense Units across the country, originally as the security wing of its local government, and which continue to act as auxiliary forces to the military. The regime has mobilized regional militias, such as the Arrow Boys and Amuka Brigade, to fight rebel groups in the north and east of the country, and the Anti-Stock Theft Unit to counter cattle raiding on the Kenyan border. The government also sponsors basic military training programs for citizens, who graduate as regime cadres. There have also been widespread rebel movements across the country including in the west, north, and east of the country, and mob violence remains widespread.

Participants of government-backed militias serve as a reservoir of violent actors for the regime, providing supplementary units when state security forces are stretched thin. They are often mobilized as manpower to support domestic policing activities, but also for other state projects ranging from developmental activities to electoral interference (Tapscott 2016). These groups are not easily disentangled from vigilantes; indeed, many of these same individuals may act as vigilantes in their communities. However, unlike vigilantes, these groups fall under a provision in the Ugandan constitution that provides for citizens to receive military training and serve as auxiliary forces. When upholding their mandate, they are "legal", and direct extensions of the state. ${ }^{2}$ As cadres of the regime, these groups can also act as informants to state security services; they are sometimes colloquially called the government's "eyes and ears." Though vigilantes at times provide the police with information about local crime, their primary function is not one of intelligence gathering for the state, but rather to enforce local law and order (also see Baker 2005).

Northern Uganda can be classified as a "most-likely" case for this study, where one would anticipate that vigilantes might be called upon to fill a security vacuum. The area is war-torn, having been the center of a twentyyear insurgency once referred to as the "world's biggest neglected crisis" due to massive civilian displacement, deplorable conditions in government and NGO-run displacement camps, forced recruitment of civilians to armed forces (whether as guerillas or government soldiers), and a resulting loss of human, social, and material capital (Allen and Vlassenroot 2010). The police only reinstated their significant presence in the north after the conflict informally ended in 2006, and have since emphasized restoring police operations in these areas (Kagoro and Biecker 2014). If any case would confirm the view that vigilantes fill a security gap, this case should do so (Eckstein 1992, 158). However, instead we observe a complex assemblage where vigilantes complement the perceived effectiveness of the other security actors. The patterns of vigilante activity observed in northern Uganda in relation to coercion, 
service provision, and authority are not unique to the north's post-conflict environment (Tapscott 2021), nor are they limited to Uganda, as highlighted in the literature review.

\section{Concept and Measurement}

The fluid and heterogeneous nature of irregular violent actors can make them difficult to study, particularly through surveys (Moncada 2017). This is especially true in contexts where alliances among violent actors are continually shifting (Bøås and Dunn 2017; Debos 2011). To address these concerns, I adopt a nested approach, starting with qualitative research to determine how best to refer to such groups in context, and then seeking to capture their activities in a household survey. Nested analysis, in which intensive case-study analysis is paired with statistical analysis, has been identified as a key political science method to facilitate valid causal inference by integrating the benefits of small- and large-N studies (Lieberman 2005; also see Auerbach and Thachil 2018 for the importance of ethnographically informed surveys). My qualitative research details complicated and interconnecting relations between vigilantes and state security actors, while the quantitative analysis shows how these dynamics aggregate to produce particular security outcomes. I have worked in Uganda since 2014, spending approximately ten months in-country (primarily in the north), tracing the activities of various vigilantes in the context of their local communities as well as how they relate to state security actors.

An additional challenge to studying such groups is their informal and sometimes illegal nature, which can implicate the researcher in a messy and at times ethically dubious space. Scholars have increasingly recognized that even while seeking to mitigate these risks, it is prudent for researchers to embrace their own limited power and unavoidable partiality, as these very constraints can facilitate access (Malejacq and Mukhopadhyay 2016). At the same time, it can be difficult to empathize with violent actors, exposing a researcher's biases, and potentially impeding data collection and subsequent analysis (Shesterinina 2019). This tension between gaining access and grappling with bias can be productive, uncovering power dynamics that shape the (micro) political environment. In my research, these tensions highlighted the extremely different but equally potent forms of violence that vigilantes and police had to hand, in the sense that both could devastate or even end lives. While vigilantes participated in violence ranging from measured canings to beating alleged thieves to death, the police wielded guns and the legal machinery of the state with a reputation for impunity.

Returning to the field repeatedly over four years allowed me to collect rich data that engages with the complexity and nuance of vigilantes as "boundary" actors (Lund 2006). First, I built a network of trusted interlocutors, who helped disentangle conflicting narratives and interpret ambiguous data. Second, I observed how actual conflicts unfolded over years through public-facing activities of vigilantes. This included attending community security meetings; local and municipal trials held to adjudicate the actions of vigilantes; and interviewing vigilantes, public authorities, community members, and police officers to triangulate narratives. I conducted over 300 semi-structured and unstructured interviews, with informal violent actors including vigilantes (32\%), civil society actors and community members (30\%), government representatives $(25 \%)$, state security actors including police and military $(11 \%)$, and traditional and religious authorities (2\%). Eighty-five percent of respondents were male, reflecting the heavily gendered nature of security sector work in Uganda. For approximately 65\% of my interviews, I worked with various Ugandan researchers, who helped to locate potential respondents and translated where necessary. Interviews covered themes including the activities of vigilantes, how they produce and claim authority, and their interactions with state authorities, particularly the police. While respondents' narratives often included ambiguous elements, when placed alongside observations of vigilantes in jail, at court, or at home, and interpreted in light of conversations with their family members, neighbors, and colleagues, clearer narratives of their relationship to society and the state began to emerge.

Based on my first four months of qualitative work, I developed survey questions on the presence, helpfulness, and activities of vigilantes that was integrated into a larger pre-existing 1,551-household survey, representative of two sub-regions of northern Uganda (Lango and Acholi), and implemented by the Secure Livelihoods Research Consortium in 2015.3 The survey question asked: "do the community peacekeepers provide the protection that people in your home need?" (In Acholi language: Lo gwok kuc me kin gang miyo kony me gwoko kuc ma dano igangi mito?) The term for "peacekeepers" (lo gwok kuc) is an emic term referring to community members who volunteer (or are volunteered) to handle local security matters, whether in the form of a consolidated vigilante group or a diffuse but collective response to insecurity in the community. I also included questions about the presence and helpfulness of the police, military, traditional authorities, and locally elected officials. ${ }^{4}$

Sources of bias in the survey appear limited. The survey contained nearly 200 questions, and was implemented in ninety randomly selected villages, pictured in figure 1. In each village, approximately twenty households were randomly identified to participate. The questions on security actors and crime were included only in the second survey round, implemented in 2015. There was an $82 \%$ retention rate between the first and 


\section{Figure 1}

\section{Map of sampled villages}

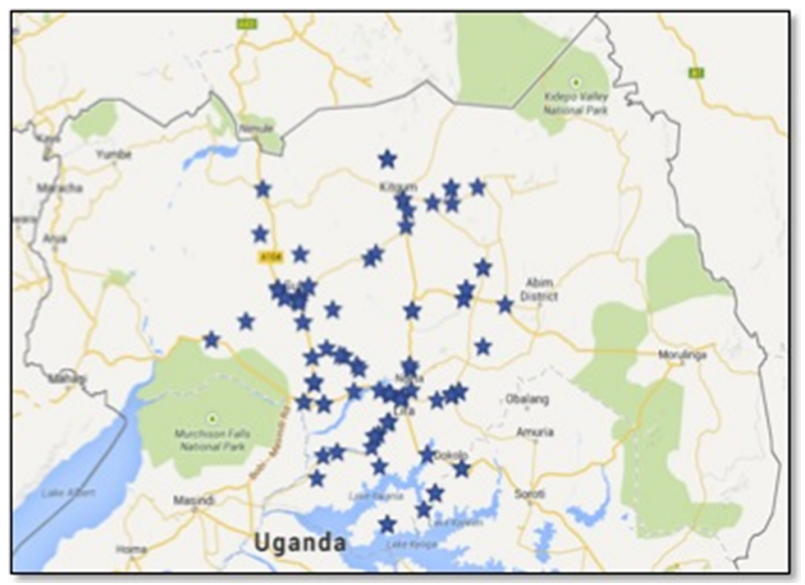

Source: Courtesy of SLRC

second rounds of the survey, and attrition was random on observable measures. Enumerators used tablets to record responses to decrease human error (see Mazurana et al. 2014 and Marshak et al. 2017 for more detailed information on the survey methodology and implementation).

\section{Qualitative Findings: Mechanisms of Complementarity between Vigilantes and the Police}

The findings show that the panoply of security actors present in northern Uganda during this time period produce a security environment that is more than the sum of its parts, with vigilantes appearing more frequently where other authorities are present, and being perceived as more helpful when other authorities are also more helpful. Focusing on the dynamics between vigilantes and the police uncovers historically embedded comparative advantages that have enabled this contingent complementarity. On one hand, the position of vigilantes is ambiguous and unstable due to the informal nature of their role, as well as their social and economic precarity; on the other hand, the police often cede responsibility to vigilantes for everyday security concerns, rely on them to deliver wrongdoers to police posts for detention, and recruit vigilantes as ad hoc manpower for police patrols. These dynamics are shaped by the historical legacies of the Ugandan police force as a coercive institution concerned more with suppressing domestic dissent than tackling local insecurity (OlokaOnyango 1990).

Uganda's vigilantes sit uncomfortably between the state and society. Vigilantism has long been a component of local social responses to crime and insecurity in Uganda.
According to Omach, vigilante activities "are rooted in the cultural norm where all adult males were expected to be armed and to participate in the defense of the community" (2010, 432). Today, they are informally tasked with using violence to enforce local order, while lacking both the legal mandate and the social standing to do so from a position of authority. Vigilantes are typically identified and recruited by locally elected village authorities called the Local Council 1 (LC1). ${ }^{5}$ Recruitment is based on one's character, as well as interest in security work, availability, and willingness to participate in security work.

Citizens sometimes lament that vigilantes might better be characterized as "crime promoters," reflecting the view that some abuse their role to engage in criminal activities including theft and extortion. Becoming a "crime promoter" can also be an unintended consequence of efforts to provide security. For example, several vigilantes that I interviewed in 2015 proudly explained that they had intervened in a domestic dispute to prevent a man from beating his wife. Several weeks later, two of the vigilantes were arrested and detained for "over-beating" the man in question; the police had determined that the vigilantes had used excessive force, placing them on the wrong side of the law. Such dynamics are ambiguous because Ugandan authorities at times exalt the virtues of vigilante and mob violence, and even instruct vigilantes to use violence to deter crime and punish suspected criminals (Tapscott 2017). Vigilantes therefore inhabit a precarious position between law enforcer and law breaker.

This ambiguity is compounded by vigilantes' social and economic vulnerabilities. Vigilantes are often described as "youths" because they lack key achievements associated with adulthood like formal marriage and stable employment. However, many are in their early 30 s and responsible for dependents including live-in girlfriends and children. They are formally unpaid, though some receive ad hoc "appreciation" from complainants, typically the equivalent of less than US $\$ 1$. Some groups also take up monthly or bimonthly collections from residents in their village, though in my research these rarely lasted more than two or three collection cycles. This precarity makes vigilantes reliant on continued support from the communities that they police.

To understand why the police might be content to cede local responsibilities to vigilantes, it is important to consider the historic roles of Uganda's police in relation to vigilantes. The Uganda Police Force emerged from a system of colonial policing that was designed primarily to discipline and control society rather than to deter crime (Oloka-Onyango 1990). The government has historically allowed the police discretion and impunity around their use of violence. Today, the Uganda Police Force is known for being highly politicized and using violence to suppress political dissent. Ordinary people have low levels of trust in the police; the Force has been ranked as the most 
corrupt institution in Uganda and East Africa over multiple years (Kiwawulo 2015). Additionally, police competencies only encompass a portion of the insecurities that people face, excluding certain social threats such as witchcraft or unsanitary living conditions. These dynamics mean that Uganda's police can outsource responsibility to vigilantes and other local actors without conferring substantial authority.

By maintaining day-to-day order in local communities, vigilantes in many ways complement the work of the police in the eyes of ordinary citizens. For instance, vigilantes are tasked with enforcing local bylaws, typically conceived of and promulgated by community members and local leaders at village security meetings, and nominally approved at the sub-county or division level to ensure that they adhere to Ugandan law. These bylaws dictate village-level rules on activities ranging from sanitation and livestock management to witchcraft and adultery. For instance, one set of bylaws specifies that "Whoever shall be found practicing ... [witchcraft, wizardry, or poisoning] shall be disciplined and expelled from the area" and that "Animals (goats) shall be free in December and shall be put on guard in March as soon as plant are put in the soil" (on file with author, minor edits made for clarity). In this capacity, vigilantes perform a social order-making role to mitigate threats that police are structurally unable or unwilling to address. For instance, though illegal in Uganda, witchcraft is difficult to adjudicate in the formal legal system; crop damage caused by livestock may seem trivial to the police, while being significant to ordinary citizens.

While vigilantes use their authority to solve many disputes locally, they can also help the community access the police. As one respondent explained:

The LC or [village] security personnel can deal with small problems. But for violence, we rush to the police ... If you go through the LC, they [the police] understand. Then they will reach you immediately, but it can be really very hard to get the police if you try to contact them directly." (22-year-old male vigilante, Gulu, October 2014)

The respondent suggests that all violent crimes are taken to the police. Though this is legally mandated, my research found that in practice, local authorities such as the LC1, traditional authorities, and vigilantes sometimes handled capital offenses, including rape and murder. More than helping the state reach down into the community, vigilantes refer cases upward, delivering wrongdoers to the police for arrest and detention.

Vigilantes further use the police-and their associated police cells, bureaucratic red tape, and reputation for corruption - in attempts to bolster their authority locally. For instance, many view the police and the penal system as an outside place to park "bad elements" or a resource to scare wrongdoers into improving their behavior. As one community member elaborated:
There are some people who are addicted to committing crimes which make it better to arrest them instead of allowing them to be at large so that they could continue committing the crime. It would give a space to breathe for his or her victims. Sometimes when a person who has been a notorious thief is arrested and put in police custody and or jail, the members of the community would then have some good time without having to bear the burden of the theft." (Male community member, Gulu, December 2014)

While vigilantes can help enforce local rules, the police have the coercive power to remove bad elements from the community so that the community can "breathe." These findings highlight how vigilantes and police conduct different work that, in this instance, complement one another.

Vigilantes are also called upon by the police and military to support the state's security priorities. Some groups reported joint patrols with the police, military, and even private security companies as often as five times per month; in these cases they reported being taken to other counties or districts where they would be unknown to the local community. This reflects the institutional structure of the Ugandan police-though vigilantes can help the police pinpoint wrongdoers in their communities, it is frequently a bottom-up process. When the police go to communities, they often take vigilantes out of their context and use them as manpower rather than intelligence, reflecting an institution that continues to rely heavily on intimidation and coercion to discipline its civilian population. As one vigilante recounted:

It can reach the point where we also refuse [to join the police on night patrol] ... If we are in another community, it is like we are trespassing there. We are not armed; we are taken to the front. People do not know who we are. We don't know the people there. (Vigilante, Gulu, February 2014)

At the same time, vigilantes can benefit from proximity to police. For example, one vigilante group elaborated that their association with the police during joint patrols both in their own community and elsewhere bolstered their authority, explaining that before they had recognition from the police:

\footnotetext{
Wrongdoers knew that the group was not recognized by the government so they had no fear of us - but we were given the go ahead by the government, and the wrongdoers realized that we had power and started respecting us ... And also the community quarrels, stealing of domestic animals, as well as the level of threats have reduced. (Focus group interview, Gulu, October 2014)
}

The complex dynamic between vigilantes and the police was clearly highlighted by the same group of vigilantes. After depicting the police as lazy and corrupt, the respondents began describing a training they had recently participated in to become "Crime Preventers"-a government community policing program: 
Each training was one month with only Sundays off ... They liked it, though it was difficult. In the past, they didn't know what laws were about or know what to do [if they identified a wrongdoer]. They are really proud if they can act in the steps of the military or police. (Field notes from focus group discussion, Gulu, October 2014).

When I asked the vigilantes why it would make them proud to act as police-who only minutes earlier they had described as corrupt and lazy - they found the question humorous. The police are state agents, receiving regular salaries, uniforms, and guns.

Examining these statements in the context of the relationship between vigilantes and state security actors is illuminating. Consider, for instance, the regime's seemingly counter-intuitive practice of promoting universal basic military training for its citizens, which builds the violent capacity of a citizenry that it must then manage through repression. However, participating in these trainings makes ordinary people aware that an alliance with the regime places one at "the right end of the gun barrel ... [so as] not to be 'shootable" (Verma 2012, 116). This view of allying with the state so as not to be disposable further extends to economic survival, as the regime's neopatrimonial system of resource distribution is heavily militarized (Tapscott 2016).

The discrepancy between disdain for police and desire to be police lay bare the discrete roles of these security actors in the assemblage. Vigilantes enforce local by-laws and are held responsible to their community through social ties. In contrast, police represent state violence and the project of controlling society, and are accountable to the ruling regime. Though they interact and can mutually benefit one another, they are not substitutes; rather, their different roles are restrained by and embedded in Uganda's broader institutional environment. In the following two sections, I use quantitative survey data to further elaborate the relationship between vigilantes and the police, and how this has been shaped by historical institutional legacies.

\section{Quantiative Findings: Examining the Security Assemblage}

\section{Vigilante's Activities and Role in Uganda's Security Assemblage}

The quantitative analysis reveals the breadth of this picture by showing trends across northern Uganda. Eighty-eight percent of respondents reported that vigilantes were present in their village. This makes them more common than other security actors, including the police (reported present by $80 \%$ of respondents) and the military (reported present by $25 \%$ of respondents). The reported presence and effectiveness of vigilantes varied signficantly, even within the same village. ${ }^{6}$ No fewer than $53 \%$ of people surveyed in any given village reported the presence of vigilantes, suggesting that a positive response was broadly inclusive of consolidated vigilante groups as well as more diffuse arrangements.

Perceptions of vigilantes' helpfulness also varied significantly both across and within villages, with respondents roughly divided on whether they are helpful or not (see graph 1.2, online appendix A). ${ }^{7}$ Though police were less regularly present than vigilantes, respondents reported that police were more consistently helpful (see graph 1.4, online appendix A). ${ }^{8}$ Personal characteristics like age, education, and gender had little impact on whether respondents perceived vigilantes as helpful (see table 1, online appendix C). This also generally holds true for respondents' perceptions of the police. ${ }^{10}$

Table 1

Individual-level characteristics (abridged)

\begin{tabular}{|c|c|c|c|c|c|c|}
\hline Variables & $\begin{array}{c}\text { (1) } \\
\text { Vigilantes are } \\
\text { present }\end{array}$ & $\begin{array}{c}\text { (2) } \\
\begin{array}{c}\text { Vigilantes are } \\
\text { helpful }\end{array}\end{array}$ & $\begin{array}{c}\text { (3) } \\
\text { Police are } \\
\text { present }\end{array}$ & $\begin{array}{l}\text { (4) } \\
\text { Police are } \\
\text { helpful }\end{array}$ & $\begin{array}{c}(5) \\
\text { Vigilantes } \\
\text { helped most }\end{array}$ & $\begin{array}{c}\text { (6) } \\
\text { Police } \\
\text { helped most }\end{array}$ \\
\hline $\begin{array}{l}\text { Experienced } \\
\text { property crime }\end{array}$ & $\begin{array}{c}0.0170 \\
(0.0288)\end{array}$ & $\begin{array}{l}-0.0279 \\
(0.0364)\end{array}$ & $\begin{array}{c}0.0750^{\star \star \star} \\
(0.0276)\end{array}$ & $\begin{array}{c}0.0361 \\
(0.0344)\end{array}$ & $\begin{array}{c}0.0987^{\star \star \star} \\
(0.0293)\end{array}$ & $\begin{array}{c}0.0650^{\star \star \star} \\
(0.0225)\end{array}$ \\
\hline $\begin{array}{l}\text { Experienced } \\
\text { social crime }\end{array}$ & $\begin{array}{l}-0.0232 \\
(0.0220)\end{array}$ & $\begin{array}{c}0.0438 \\
(0.0371)\end{array}$ & $\begin{array}{l}-0.0453^{\star} \\
(0.0271)\end{array}$ & $\begin{array}{c}-0.00649 \\
(0.0320)\end{array}$ & $\begin{array}{l}0.0411^{\star \star} \\
(0.0187)\end{array}$ & $\begin{array}{l}0.0773^{\star \star \star} \\
(0.0207)\end{array}$ \\
\hline $\begin{array}{l}\text { Experienced } \\
\quad \text { violent crime }\end{array}$ & $\begin{array}{c}0.0270 \\
(0.0260)\end{array}$ & $\begin{array}{l}-0.0683 \\
(0.0434)\end{array}$ & $\begin{array}{l}-0.0640^{*} \\
(0.0368)\end{array}$ & $\begin{array}{l}-0.104^{\star *} \\
(0.0509)\end{array}$ & $\begin{array}{c}0.0853^{\star \star \star *} \\
(0.0312)\end{array}$ & $\begin{array}{l}0.240^{\star \star \star} \\
(0.0318)\end{array}$ \\
\hline $\begin{array}{l}\text { Measure for } \\
\text { assets }\end{array}$ & $\begin{array}{l}-0.00488 \\
(0.00478)\end{array}$ & $\begin{array}{c}0.00166 \\
(0.00728)\end{array}$ & $\begin{array}{l}-0.0115^{\star *} \\
(0.00451)\end{array}$ & $\begin{array}{l}-0.00754 \\
(0.00689)\end{array}$ & $\begin{array}{l}-0.00553 \\
(0.00593)\end{array}$ & $\begin{array}{l}0.0222^{\star \star \star} \\
(0.00586)\end{array}$ \\
\hline Constant & $\begin{array}{l}0.913^{\star \star \star} \\
(0.0603)\end{array}$ & $\begin{array}{c}0.146^{\star} \\
(0.0869)\end{array}$ & $\begin{array}{l}0.734^{\star \star \star} \\
(0.0801)\end{array}$ & $\begin{array}{l}0.422^{\star \star \star} \\
(0.105)\end{array}$ & $\begin{array}{l}-0.0328 \\
(0.0696)\end{array}$ & $\begin{array}{l}-0.0396 \\
(0.0678)\end{array}$ \\
\hline Observations & 1,229 & 1,079 & 1,270 & 1,018 & 741 & 741 \\
\hline$R$-squared & 0.019 & 0.194 & 0.060 & 0.114 & 0.094 & 0.166 \\
\hline
\end{tabular}

Note: Refer to online appendix $C$ for full results. Robust standard errors in parentheses. ${ }^{\star \star *} p<0.01,{ }^{\star \star} p<0.05,{ }^{*} p<0.1$ 


\section{Figure 2}

\section{Who did you go to? Acholi sub-region (SLRC 2015)}

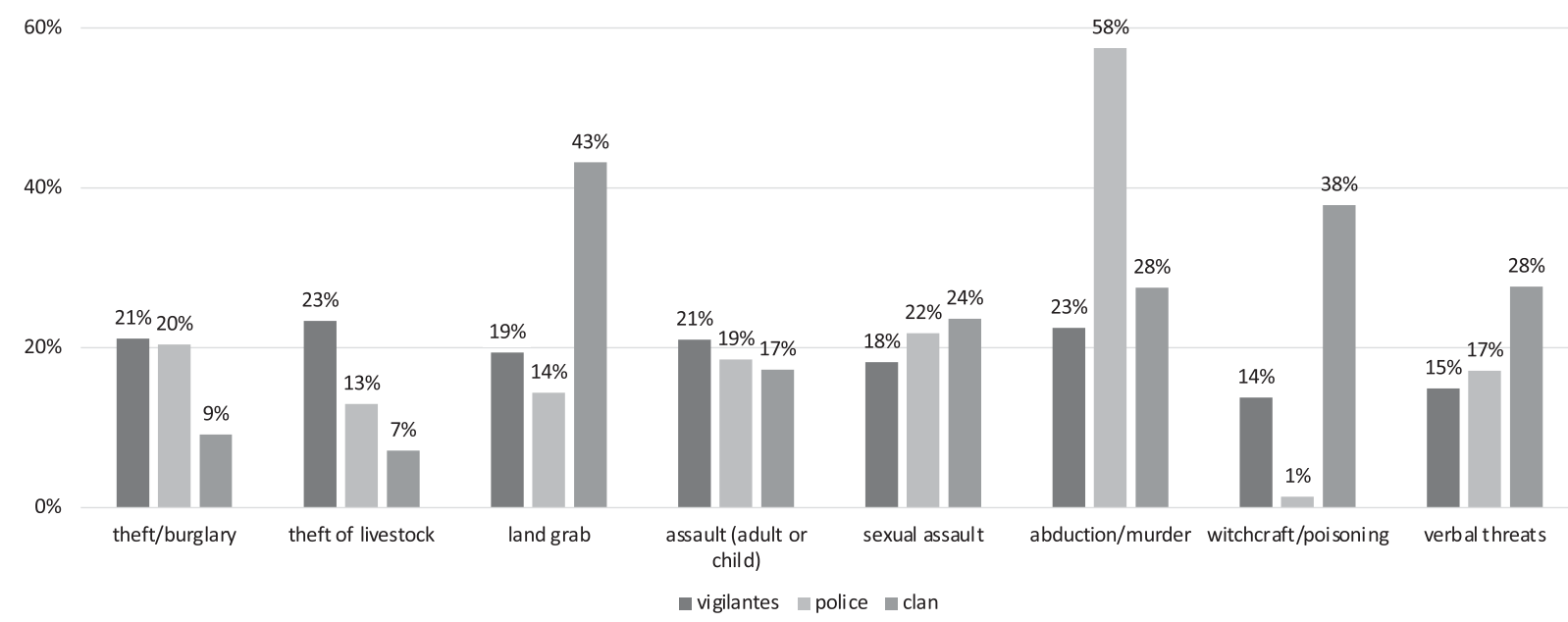

Note: The question asked, "How did your family deal with this [crime]?" and prompted respondents with nine potential security and governance actors including police and vigilantes.

Age was the most important personal characteristics for one's assessment of vigilantes. For each additional year in age of the respondent, it was approximately $0.2 \%$ more likely the respondent would rate vigilantes as providing the security their household needs sometimes or always at a statistically significant level. This small but statistically significant relationship is likely attributable to two trends: first, the local norms that vigilantes reinforce are typically socially conservative and traditional, upholding the authority of the elderly. Second, youth are often considered a source of insecurity in communities and thus more likely to have negative run-ins with vigilantes.

A measure for political preference shows that respondents who feel the central government cares about them and their opinions is correlated with a nearly $7 \%$ increase in the likelihood that they report the presence of vigilantes, and a nearly $6 \%$ increase in the likelihood that they find vigilantes helpful (see table 1, online appendix C). On the same measure, for the police, there is no statistically significant increase in the likelihood of reporting that police are present, but a $7 \%$ increase in the likelihood that respondents will find the police helpful. The positive relationship between reporting that the central government cares and that vigilantes are present is robust across various models, but not with the helpfulness of vigilantes. It is unlikely that sentiment toward the central government makes people more likely to report the presence of vigilantes, and therefore, I posit that the robust relationship between reporting vigilante presence and a positive assessment of the central government is because they work synergistically with the police and help resolve security concerns that the police as an institution is not well designed to address, such that citizens feel more positively about the government.

When respondents reported their actual experiences with vigilantes and other authorities-rather than their perceptions of helpfulness-vigilantes emerge as important actors, even compared to the police (see figures 2 and 3-these charts include vigilantes and police, as well as traditional authorities or "clan"-included to offer additional context to interpret the magnitudes for police and vigilantes). Community members seek assistance from vigilantes as often or more often than they go to police for property crimes (theft, theft of livestock, burglary, land grabbing), some violent crimes (physical assault), and almost as often for sexual assault. They also go to vigilantes more often than to police for crimes of witchcraft and poisoning. ${ }^{11}$ Violent crimes are most often taken to the police and the locally elected government representative (LC1); refer to figure 2. A clearer pattern emerges when respondents report who helped them most, based on their experience of a specific crime; refer to figure 3 .

\section{Experience of Crime and Perceptions of Vigilantes}

To further probe the relationship between experiences and perceptions, I used an OLS regression to see whether people who experienced crimes found vigilantes more or less helpful. I examined how this might differ by type of crime. For example, crimes like theft, burglary, and physical assault could be prevented by increased vigilance such as nighttime patrols, while crimes like verbal threats, 


\section{Figure 3}

\section{Who helped most? Acholi sub-region (SLRC 2015)}

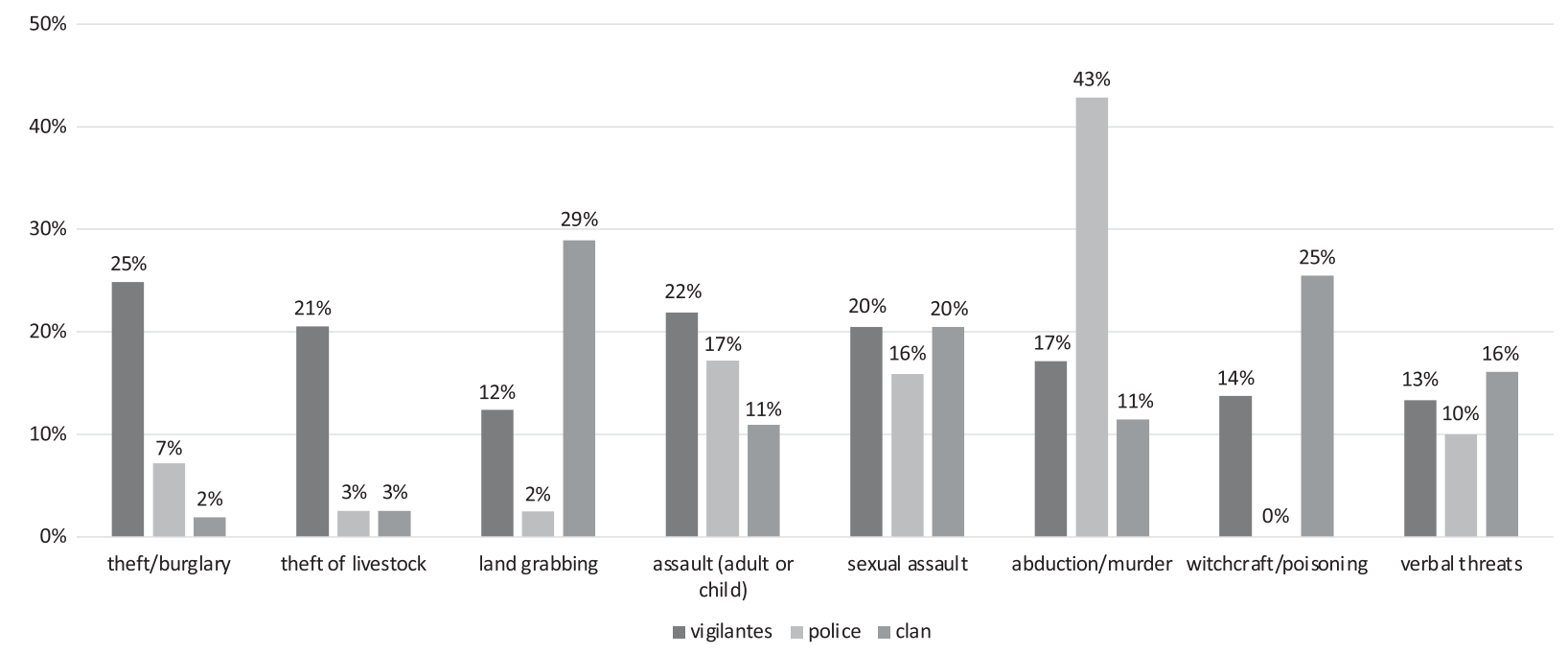

Note: The question asked, "Which one [of the security or governance actors you went to] was best able to help you?" The graph shows percentages of those who experienced the crime.

witchcraft, and poisoning may be more resilient to increased vigilance. To explore this, I tested the following:

$$
\begin{aligned}
& \text { presence/helpfulness of security actor/ } \\
& \text { helped most }=\mathrm{a}+\mathrm{b}\left(\text { crime }^{12}\right)+\text { controls }
\end{aligned}
$$

The model tests three types of dependent variable: first, "presence", which is a dichotomous variable coded as 1 if respondents reported that a given actor was present, and 0 if not. The second dependent variable looks at respondents' perceptions of said actor in a variable called "helpfulness". This is also a dichotomous variable, coded as 0 when respondents reported that a given actor provided security rarely or never, and as 1 when they reported they provided security sometimes or always. The third dependent variable describes whether a given actor was reported as being the most helpful for resolving a crime. It is also dichotomous. The question on crime asked whether anyone in the household had experienced each type of crime between 2013 and 2015. I aggregated the given crimes into three categories: property crime, including theft, burglary, and land grabbing; violent crimes, including abduction, murder, harm to a child, and sexual or physical assault; and social crimes, including witchcraft, poisoning, and verbal threats. These crimes are all multidimensional; this simplified categorization is based on my qualitative field research and helps identify behavioral patterns.

I included several controls for individual characteristics (age, gender, education). I also included a measure for assets, based on land and home ownership, ownership of material assets (like a mattress, cell phone, or bike), and livestock, which serves as both an indicator of wealth and potentially of the respondent's perceptions of a need to secure or protect these assets. Greater wealth could allow respondents to pay security providers, increasing responsiveness and efficacy. I also included a measure of how safe the respondent feels in their community, to account for social cohesion of the community; a measure for whether the respondent was in an urban or rural setting, which impacts the presence of state infrastructure and services; a measure of social capital, derived from whether respondents reported they would be able to borrow money from a neighbor; a measure for the respondent's political leanings, measured by whether the respondent reported that the central government cares about them and their opinions; as well as for the district, where important security-related decisions are made; and subregion (Acholi versus Langi). I clustered at the village level to account for the likely similar security environments within each village. I describe the results specifically for experience of different kinds of crime, focusing on findings that are significant at the $95 \%$ level of significance or above.

Experiences of crime at aggregated and disaggregated levels have no statistically significant impact on a respondents' likelihood to report helpful vigilantes. Experiencing a property crime is correlated with a $7.5 \%$ increase in likelihood to report the presence of police. As with more highly educated respondents, this increased awareness likely reflects respondents who have more information on the police and their activities. 
Respondents who reported experiencing a property crime were 9.8 percentage points more likely to report that vigilantes helped them most for any crime they experienced, while those who experienced a violent crime in the same time period were 8.5 percentage points more likely to say that vigilantes helped them most for any crime they experienced, both at a 99\% confidence level. Respondents who experienced violent crimes reported that the police are most helpful nearly three times more than they said vigilantes were most helpful; those who experienced social crimes were almost twice as likely to report that the police helped them most compared to vigilantes. This relationship is inverted for property crimes, where respondents were more likely to say vigilantes (and not the police) helped them most, at a 99\% confidence level. ${ }^{13}$

The findings show that vigilantes are more helpful for resolving property crimes than other types of crime, and citizens on average experience them as more helpful than the police in this endeavor. In addition to the different roles that police and vigilantes play, this likely further reflects vigilantes' preferential access to local knowledge that they can use to locate stolen goods, even while they may lack the violent capacity needed to decisively resolve more serious crimes. In a security assemblage, different security providers can play to their comparative advantages. Vigilantes can address relatively minor issues, such as infractions where a one-time fine or beating may be sufficient to adjust behavior, or crimes like thefts that require investigations and detailed knowledge of the community to solve. In contrast, police remain separate from the community and are accountable to the ruling regime. They thus maintain coercive capacity and independence from society that enable them to remove bad elements from the community (see also Sigler and King 1992).

\section{Presence and Effectiveness of Vigilantes}

In northern Uganda, the presence of vigilantes is positively correlated with the presence of other public authoritiesincluding LC1, police, military, and traditional authorities - and ordinary citizens perceive them as more helpful in this environment. I analyze this with the following model:

presence/ helpfulness of vigilantes $=\mathrm{a}+\mathrm{b}$ (presence/
helpfulness of other security providers) + controls

The key dependent variables-presence and helpfulness of vigilantes - are the same as those used in model 1. The key independent variables of interest are the presence and perceived effectiveness of the public authorities listed earlier. To measure the presence of other public authorities, I created a scalar variable that measures the number of public authorities a respondent reports present (from 0 if none were present, to 4 if the respondent reported that military, police, traditional authorities, and LC1s were present). ${ }^{14}$ To measure perceived effectiveness of public authorities, I created a variable that measures the proportion of present public authorities that the respondent reported were helpful sometimes or always. ${ }^{15}$ I first tested whether vigilante presence was correlated with the presence of other public authorities, including the police, the military, traditional authorities, and the LC1. In a second set of regressions, I tested whether presence of vigilantes is correlated with the perception that other public authorities were helpful, and finally whether the perception that vigilantes were helpful was correlated with the perception that other public authorities were helpful. In addition to the controls used in model 2, I added controls for experiencing property crimes, social crimes, and violent crimes.

The findings show that for each additional public authority that a respondent reported present, there is a 9.4 percentage point increase in the probability that they will also report that vigilantes are present (table 2, column 1). The findings also show that the presence of additional public authorities (rather than their perceived helpfulness) account for respondents' increased likelihood to report the presence of vigilantes (table 2, column 2). Similarly, respondents who reported the presence of more public authorities did not view vigilantes as more helpful (table 2, column 3). Said differently, the helpfulness of vigilantes is not correlated with the mere presence of other public authorities, instead it is correlated with the helpfulness of those other public authorities. In this case, more helpful public authorities appear to beget more helpful vigilantes. The relationship is substantial and significant. These findings are robust when using different thresholds to measure the helpfulness of vigilantes, and when excluding the twenty villages where $100 \%$ of respondents reported that vigilantes were present.

\section{Discussion: How the Assemblage Shapes Security Outcomes and State Authority}

This study offers several insights for scholarship on nonstate armed actors and what they reveal about the state's ability to control violence. The findings clearly show that security is not zero-sum. As the quantitative analysis shows, the presence of vigilantes is associated with the presence of other public authorities, and vigilantes are seen to be more helpful where other public authorities are also perceived as more helpful. The presence of vigilantes is not associated with higher crime rates, which could indicate a higher demand for policing, nor is it linked to perceptions of insecurity, which could indicate an absence of security provision. Instead, it is positively correlated to police presence, suggesting that under some circumstances, 


\section{Table 2}

Vigilantes in the security assemblage (abridged)

\begin{tabular}{|c|c|c|c|c|}
\hline Variables & $\begin{array}{c}\text { (1) } \\
\text { Vigilantes are } \\
\text { present }\end{array}$ & $\begin{array}{c}\text { (2) } \\
\text { Vigilantes are } \\
\text { present }\end{array}$ & $\begin{array}{c}\text { (3) } \\
\begin{array}{c}\text { Vigilantes are } \\
\text { helpful }\end{array}\end{array}$ & $\begin{array}{c}(4) \\
\begin{array}{c}\text { Vigilantes are } \\
\text { helpful }\end{array}\end{array}$ \\
\hline $\begin{array}{l}\text { Number of public authorities present } \\
(0-4)\end{array}$ & $\begin{array}{c}0.0936^{\star * *} \\
(0.0145)\end{array}$ & & $\begin{array}{l}0.00954 \\
(0.0184)\end{array}$ & \\
\hline $\begin{array}{l}\text { Proportion of public authorities } \\
\text { perceived as helpful }\end{array}$ & & $\begin{array}{c}-0.00560 \\
(0.0321)\end{array}$ & & $\begin{array}{l}0.478^{\star \star \star} \\
(0.0449)\end{array}$ \\
\hline Constant & $\begin{array}{l}0.596^{\star * *} \\
(0.0747)\end{array}$ & $\begin{array}{l}0.882^{\star \star \star} \\
(0.0500)\end{array}$ & $\begin{array}{l}0.205^{\star *} \\
(0.0833)\end{array}$ & $\begin{array}{l}0.000140 \\
(0.0639)\end{array}$ \\
\hline $\begin{array}{l}\text { Observations } \\
\text { R-squared }\end{array}$ & $\begin{array}{l}1,284 \\
0.053\end{array}$ & $\begin{array}{l}1,284 \\
0.015\end{array}$ & $\begin{array}{l}1,126 \\
0.186\end{array}$ & $\begin{array}{l}1,126 \\
0.268\end{array}$ \\
\hline
\end{tabular}

Notes: Refer to online appendix $C$ for full result. Robust standard errors in parentheses ${ }^{\star \star \star} p<0.01,{ }^{\star \star} p<0.05,{ }^{*} p<0.1$

public authorities whether state or non-state can act in concert to improve security. In this instance, this historically contingent arrangement means that vigilantes and the police complement one another in an assemblage that produces more than the sum of its parts, such that helpful public authorities beget helpful vigilantes.

Examining how different public authorities relate to one another, and how this is shaped by institutional legacies, offers explanations for this contingent complementarity, with useful insights for other low-capacity states. For instance, when vigilantes overstep their remit, citizens can make complaints to other authorities, including police, traditional authorities, or the military. These public authorities can then reassert limits on vigilantes' work. For example, a Defense Secretary on the Local Council explained that mob violence is tempered by police presence:

As much as they like mob justice, they also remember the police. While they are beating you, they are also dragging them to the police. (Gulu District, October 16, 2014)

When public authorities are active and engaged (e.g., helpful), vigilantes are more likely to "remember" the possibility that they will be held accountable. If the police can help victims that vigilantes refer to them or if they detain or punish wrongdoers that vigilantes deliver to them, the community is more likely to be satisfied with the role that vigilantes play. These collaborations have their own material and reputational effects, as vigilantes sometimes derive authority from their associations with public authorities and the concomitant access to material and symbolic forms of violence and power.

Public authorities can also benefit from effective vigilantes. Recent research has shown that ordinary Ugandans have low trust in police in part because of co-ethnic bias and the frequent transfer of police officers (Curtice 2019). In this environment, vigilantes can serve as a bridge between the police and local communities, translating community needs to the authorities. Additionally, local politicians such as the LC1 sometimes build popularity by claiming credit for perceived security gains provided by vigilantes, or offering vigilantes as evidence that they are "hard on crime." Several of my respondents explained that initiating security groups and giving them verbal permission to use corporal punishment against criminals can support this reputation. For example, during the conflict, the mayor of Gulu had a reputation for having encouraged and even committed extra-judicial violence in the name of law-and-order, earning him the nickname, "Labeja nek gi" or "Labeja, he killed them" (also see Omach 2010). Some respondents have cited this as the basis for his popularity, and suggest that he will become less influential as Gulu continues to become more peaceful.

The findings also illustrate that the existing institutional landscape shapes the extent to which low-capacity states can strategize their relationship to non-state violent actors. Limited capacity means that the state simply cannot work independently of other violent actors. As a result, many actors including vigilantes take on different roles to create the current Ugandan security environment. In this instance, rather than replace police, vigilantes serve a complementary role managing many day-to-day security concerns. Police generally allow them to do so, while retaining the ability to determine post-hoc that vigilante activities were illegal and are punishable by law. In this way, police maintain authority, even while other local actors like vigilantes also use coercion to engage in social order-making. This allows the police to maintain its historically rooted focus of policing society for the purposes of regime control, not social welfare.

This analysis both complements and departs from some other studies that engage the complexity of diverse violent actors. For instance, Marks, Shearing, and Wood (2009) advocate a "nodal" or "networked" approach to study different jurisdictions of violent actors in South Africa. 
While they similarly emphasize the unique role of the police "to use ubiquitous coercion in a graduated and discretionary way" (ibid., 151) and strategically devolve responsibility for difficult security problems to civic and private actors, they also suggest that police "desire to maintain what they view as their established monopoly of the policing enterprise" (ibid., 145). They propose the notion of "partnerships" among police and other violent actors, implying a shared goal or vision of security that together they can provide. They further emphasize that the police's difficulty engaging civil society actors is an "inevitable result of the police holding onto their monopolization dream and their inability to imagine what a more diverse and complex (and much messier) policing matrix may look like" (ibid., 148). I instead propose a focus on the different relationships and historically informed roles of violent actors, revealing that their agendas have fundamental differences such that the police may want to control certain kinds of violence, and not others. This means that these different violent actors can co-exist, interrelate, and layer on top of one another thereby potentially creating assemblages with qualitatively particular security outcomes, rather than filling gaps in state security provision.

\section{Security Assemblages: Rethinking the State's Control over Violence}

This mixed-methods analysis of local security in northern Uganda illustrates how a security assemblages approach can uncover important characteristics of the state's control over violence. The findings show that, in this case, vigilantes emerged as complementary and auxiliary actors to public authorities, and were viewed as more helpful where public authorities were also more helpful. The complementary arrangement is not a feature of an assemblage per se; rather, this approach reveals the importance of historical contingencies and institutional legacies. Actors in a security assemblage may be mutually reinforcing; they may also contradict or undermine one another. Moreover, even if we observe an overall pattern of complementarity or conflict within any given security assemblage, there may be variation and contradiction in individual relationships or interactions: in northern Uganda, even though the aggregate relationship between police and vigilantes is complementary from the perspective of ordinary citizens, the dynamic is also characterized by important ambiguities, conflicts, and contradictions.

The article focused on the police to help understand the quality of the state's monopoly on violence, revealing how a state with a highly fragmented and complex security arrangement outsources daily security provision and maintains the police as an institution to control society rather than deter crime. This analysis reflects a single snapshot in time, capturing a temporally and spatially delimited view of the security assemblage in Gulu between 2014 and 2018. It shows how, in this historically contingent arrangement, police and vigilantes do not substitute for one another, but instead play fundamentally different roles that are mutually reinforcing and contribute to perceived effectiveness of the state.

By examining Uganda's vigilantes as relational and historically embedded actors in a security assemblage, the findings show that these vigilantes can draw authority from other security and governance actors, but are also highly constrained by their presence and oversight. Uganda's ruling regime benefits from engaging civilians in security provision. The regime has no responsibility to train, pay, or maintain vigilantes; and it can disown them as bandits, criminals, or opportunists if they step out of line. These dynamics remain central to the enduring role of the Ugandan police, even as they receive international condemnation for violently suppressing political events, arresting opposition candidates, and using live ammunition and teargas to disperse crowds, causing multiple civilian casualties (Al Jazeera 2020; Associated Press 2020). Importantly, this article makes no normative claim about vigilante violence or police activity, instead using the assemblages approach to examine empirically how ordinary people perceive security outcomes under complex arrangements.

The findings offer three contributions to studies of the state's control over violence: first, local security is not zero-sum. Rather than seeing violent actors as emerging to fill a security gap, they might be helpfully conceptualized as relating to-and in some instances layering on top of-one another, thickening the security environment. This changing environment may provide additional securities and benefits for some, while at the same time, creating insecurities and hostilities for others, as evidenced by the violent and heavily politicized actions of the Ugandan police. Second, it shows that different actors are structurally suited to provide different kinds of security-and these comparative advantages have important path dependencies. Different security actors should not be read as substitutes, or as necessarily seeking to supplant one another. Instead, we must look to their historically contingent interactions to see how they reinforce or undermine one another and what particular security outcomes these interactions produce. Third, as a result, the presence of non-state violent actors should not be read as an indicator of state weakness or failure, but rather as part of a broader security assemblage in which violent actors, including institutions of the state, are sometimes constrained in terms of who they work with and how. These findings bolster emerging insights that reveal non-state violent actors as part of a complex governing environment rather than as filling a 
governance gap, and illustrate the utility of a security assemblages approach to interpret the prevalence and activities of non-state violent actors.

\section{Acknowledgement}

For helpful suggestions on earlier drafts, the author thanks Jenny Aker, Deval Desai, Brian Kubris, Dyan Mazurana, Eduardo Moncada, Neeraj Prasad, Paul Staniland, and Lore Vandewalle, as well as audiences at the American Political Science Association's 2019 and 2020 annual meetings. Four anonymous reviewers and the editors at Perspectives on Politics provided extremely thoughtful and constructive comments. The Secure Livelihoods Research Consortium gave access to its survey data, and the London School of Economics' Centre for Public Authority and International Development and the Gerda Henkel Foundation funded fieldwork in Uganda. The author thanks particularly Raphael Kerali and Francis Abonga for research assistance in Uganda.

\section{Notes}

1 I use the term "public authorities" to encapsulate a set of authorities specified later in the paper; Hoffman and Kirk 2013.

2 These various irregular armed groups, while initiated and backed by the state, are often disowned. For instance, during the recent coronavirus pandemic, the government used local defense units to enforce a lockdown. When communities condemned the groups for indiscriminate beating of citizens to enforce the measures, the government called for the arrest and detention of the local defense units.

3 The Secure Livelihoods Research Consortium was established at the Overseas Development Institute in 2011 to support evidence-based policy on livelihoods and services in conflict-affected situations. For additional details on its methodology, see Mazurana et al. 2014 and Marshak et al. 2017.

4 The survey also asked about a community policing group called "Crime Preventers." I have omitted them from analysis because of concerns of double counting between vigilantes and Crime Preventers. The remaining actors included in the survey are sufficiently distinct that respondents would not confuse them with one another, mitigating the risk of double counting.

5 Uganda's government relies on a five-tiered structure of democratically elected councils, starting from the local council 1 (LC1) at the village level, up to the local council 5 (LC5) at the district level. The LC1 serves as a local administrator, and can respond to ad hoc village governance needs.

6 In twenty villages, $100 \%$ of respondents reported that vigilantes were present. In the remaining 70 villages, between $53 \%$ and $95 \%$ of respondents reported that vigilantes were present in the community (refer to online appendix A, graph 1.1).

7 Responses to the question of whether vigilantes provided the security that households needed aggregated to a village level have a regular distribution, with a mean of 0.55 and a standard deviation of 0.26 .

8 Police helpfulness has a mean of 0.62 and a standard deviation of 0.21 .

9 Higher levels of education and being a woman had small negative but statistically nonsignificant relationship to finding vigilantes helpful, while asset ownership had an inconsistent and non-statistically significant relationship.

10 Education is positively correlated with reporting police presence (but not helpfulness) at a statistically significant level, suggesting that education may enable respondents to understand and use police services more effectively. For example, in my research, respondents often said that the police do not do their work properly because a suspect is arrested and then released, even in cases when this is because there is insufficient evidence to detain the suspect, and therefore the suspect legally must be released.

11 In addition to referring to the ingestion of a lethal substance, poisoning in local context refers to a particular kind of witchcraft that results in sudden and unexplained death (Storer, O’Byrne, and Reid 2017).

12 I also tested each crime individually; none were statistically significant.

13 The underlying correlation is unsurprising - the survey asked those who experienced crimes who helped them most and respondents could list three actors in any order. Therefore, it is the magnitude of the correlation that is of interest.

14 To see each public authority tested individually, refer to table 3 in online appendix C. I grouped public authorities together here to maintain a larger sample size, and to show the effect more clearly. Table 3 does not test for LC1s as they are reported present by virtually all respondents and therefore do not offer sufficient variation.

15 To see each public authority's effectiveness tested individually, refer to table 3 in online appendix $\mathrm{C}$.

\section{Supplementary Materials}

Appendix A. Presence and Effectiveness of Vigilantes and Police Aggregated by Village.

Appendix B. Who Respondents Went to for Help with Crimes experienced between 2013-2015, Disaggregated by crime, in Acholi Sub-Region.

Appendix C. Regressions Output Tables.

To view supplementary material for this article, please visit http://doi.org/10.1017/S1537592721001134. 


\section{References}

Abrahams, Ray. 1998. Vigilant Citizens: Vigilantism and the State. Oxford: Polity Press.

Abrahamsen, Rita, and Michael Williams. 2010. Security beyond the State: Private Security in International Politics. New York: Cambridge University Press.

Ahram, Ariel. 2011. Proxy Warriors: The Rise and Fall of State-Sponsored Militias. Stanford: Stanford University Press.

Al Jazeera. 2020. "Deadly Protests in Uganda after Bobi Wine Arrested Again," November 18 (https:// www.aljazeera.com/news/2020/11/18/bobi-wineuganda-opposition-presidential-candidate-arrested).

Allen, Tim, and Koen Vlassenroot. 2010. The Lord's Resistance Army: Myth and Reality. London: Zed Books.

Associated Press. 2020. "Uganda Police Arrest Opposition Figure, Setting Off Deadly Protests.” New York Times, November 18 (https://www.nytimes.com/2020/11/ 18/world/africa/uganda-police-arrest-oppositionfigure-setting-off-deadly-protests.html).

Auerbach, Adam Michael, and Tariq Thachil. 2018. "How Clients Select Brokers: Competition and Choice in India's Slums." American Political Science Review 112(4): 775-91.

Baker, Bruce. 2005. "Multi-Choice Policing in Uganda." Policing and Society: An International Journal of Research and Policy 15(1): 19-41.

Bøås, Morten, and Kevin Dunn. 2017. Africa's Insurgents: Navigating an Evolving Landscape. Boulder, CO: Lynne Rienner.

Buur, Lars, and Steffen Jensen. 2004. "Introduction: Vigilantism and the Policing of Everyday Life in South Africa." African Studies 63(2): 139-52.

Carey, Sabine, Neil Mitchell, and Will Lowe. 2013. "States, the Security Sector, and the Monopoly of Violence: A New Database on Pro-Government Militias." Journal of Peace Research 50(2): 249-58. Chowdhury, Arjun. 2018. The Myth of International Order: Why Weak States Persist and Alternatives to the State Fade Away. Oxford: Oxford University Press.

Cooper-Knock, Sarah Jane, and Olly Owen. 2014. "Between Vigilantism and Bureaucracy: Improving Our Understanding of Police Work in Nigeria and South Africa." Theoretical Criminology 19(3): 355-75.

Curtice, Travis. 2019. "Police and Coethnic Bias in Autocracies: Evidence from Two Experiments in Uganda." Harvard Experiments Working Group (https://traviscurticedotcom.files.wordpress.com/ 2019/08/curtice_jmp_august_2019.pdf).

Debos, Marielle. 2011. "Living by the Gun in Chad: Armed Violence as a Practical Occupation." Journal of Modern African Studies 49(3): 409-28.
Eckstein, Harry. 1992. Regarding Politics: Essays on Political Theory, Stability, and Change. Berkeley: University of California Press.

Glawion, Tim. 2020. The Security Arena in Africa: Local Order-Making in the Central African Republic, Somaliland, and South Sudan. Cambridge: Cambridge University Press.

Hoffman, Kasper, and Thomas Kirk. 2013 "Public Authority and the Provision of Public Goods in Conflict-Affected and Transitioning Regions." Justice and Security Research Programme, International Development Department, London School of Economics and Political Science, London, UK.

Harkness, Kristen A. 2016. "The Ethnic Army and the State: Explaining Coup Traps and the Difficulties of Democratization in Africa." Journal of Conflict Resolution 60(4): 587-616.

Heald, Suzette. 2006. "State, Law, and Vigilantism in Northern Tanzania." African Affairs 105(419): 265-83.

Higate, Paul, and Mats Utas, eds. 2017. Private Security in Africa: From the Global Assemblage to the Everyday. Africa Now. Uppsala: Zed Books.

Jaffrey, Sana. 2020. "In the State's Stead? Vigilantism and Policing of Religious Offence in Indonesia." In Democracy in Indonesia: From Stagnation to Regression? ed. Thomas Power and Eve Warburton, 303-25. Singapore: ISEAS_-Yusof Ishak Institute.

Johnston, Les. 1996. "What Is Vigilantism?” British Journal of Criminology 36(2): 220-36.

Kagoro, Jude, and Sarah Biecker. 2014. "For Whom Do the Police Work? The Ugandan Police between Militarization and Everyday Duties." Working Paper, Institute for Intercultural and International Studies, University of Bremen.

Kiwawulo, Chris. 2015. "Police Top Corrupt Institution-Report." New Vision, December 16 (https://www.newvision.co.ug/news/1413659/ police-corrupt-institution-report).

Lieberman, Evan. 2005. "Nested Analysis as a MixedMethod Strategy for Comparative Research." American Political Science Review 99(3): 435-52.

Lund, Christian. 2006. "Twilight Institutions: An Introduction." Development and Change 37(4): 673-84.

Malejacq, Romain, and Dipali Mukhopadhyay. 2016. "The 'Tribal Politics' of Field Research: A Reflection on Power and Partiality in 21st-Century Warzones." Perspectives on Politics 14(4): 1011-28.

Marks, Monique, Clifford Shearing, and Jennifer Wood. 2009. "Who Should the Police Be? Finding a New Narrative for Community Policing in South Africa." Police Practice and Research 10(2): 145-55.

Marshak, Anastasia, Dyan Mazurana, Jimmy Hilton Opio, Rachel Gordon, and Teddy Atim. 2017. "Tracking Change in Livelihoods, Service Delivery and 
Governance Evidence from a 2013-2015 Panel Survey in Uganda.” Working Paper 59. London: Secure Livelihoods Research Consortium (https://secureliveli hoods.org/wp-content/uploads/SLRC_Evidence_ 2012-2018_Panel_Survey_Uganda.pdf).

Mazurana, Dyan, Anastasia Marshak, Jimmy Hilton Opio, and Rachel Gordon. 2014. "Surveying Livelihoods, Service Delivery and Governance: Baseline Evidence from Uganda." Working Paper 12. Secure Livelihoods Research Consortium (https:// securelivelihoods.org/publication/surveyinglivelihoods-service-delivery-and-governance-baselineevidence-from-uganda-2/).

Meagher, Kate. 2007. "Hijacking Civil Society: The Inside Story of the Bakassi Boys Vigilante Group of South-Eastern Nigeria." Journal of Modern African Studies 45(1): 89-115.

Moncada, Eduardo. 2017. "Varieties of Vigilantism: Conceptual Discord, Meaning and Strategies." Global Crime 18(4): 403-23.

Müller, Martin. 2015. "Assemblages and Actor-Networks: Rethinking Socio-MaterialPpower, Politics and Space." Geography Compass 9(1): 27-41.

Mukhopadhyay, Dipali. 2014. Warlords, Strongman Governors, and the State in Afghanistan. Cambridge: Cambridge University Press.

Mutahi, Patrick. 2011. "Between Illegality and Legality: (In)Security, Crime and Gangs in Nairobi Informal Settlements." South African Crime Quarterly 37:11-18.

North, Douglass C., John Joseph Wallis, and Barry R. Weingast. 2009. Violence and Social Orders: A Conceptual Framework for Interpreting Recorded Human History. Cambridge: Cambridge University Press.

Oloka-Onyango, Joe. 1990. "Police Powers, Human Rights, and the State in Kenya and Uganda: A Comparative Analysis." Third World Legal Studies 9(1): 1-36.

Olson, Mancur. 2000. Power and Prosperity. New York: Basic Books.

Omach, Paul. 2010. "Political Violence in Uganda: The Role of Vigilantes and Militias." Journal of Social, Political, and Economic Studies 35(4): 426-49.

Ong, Lynette. 2018. “'Thugs-for-Hire': Subcontracting of State Coercion and State Capacity in China." Perspectives on Politics 16(3): 680-95.

Pratten, David, and Atreyee Sen, eds. 2008. Global Vigilantes. New York: Columbia University Press.

Rasmussen, Jacob. 2017. "Political Becoming and Non-State Emergence in Kenya's Security Sector: Mungiki as Security Operator." In Private Security in Africa: From the Global Assemblage to the Everyday, ed. Paul Higate and Mats Utas, 120-41. London: Zed Books.

Ray, Subhasish. 2013. "The Nonmartial Origins of the 'Martial Races': Ethnicity and Military Service in Ex-British Colonies." Armed Forces \& Society 39(3): 560-75.

Reno, William. 2011. Warfare in Independent Africa. New York: Cambridge University Press.

Shesterinina, Anastasia. 2019. "Ethics, Empathy, and Fear in Research on Violent Conflict." Journal of Peace Research 56(2): 190-202.

Sigler, Robert T., and David J. King. 1992. "Colonial Policing and Control of Movements for Independence." Policing and Society 3(1): 13-22.

Smith, Nicholas Rush. 2019. Contradictions of Democracy: Vigilantism and Rights in Post-Apartheid South Africa. Oxford: Oxford University Press.

Staniland, Paul. 2017. "Armed Politics and the Study of Intrastate Conflict." Journal of Peace Research 54 (4): 459-67.

Storer, Elizabeth, Ryan O’Byrne, and Kyla Reid. 2017. "Poisoning at the Periphery: Allocating Responsibility across the Uganda/South Sudan Borderlands." Third World Thematics 2(2-3): 180-96.

Tapscott, Rebecca. 2016. "Where the Wild Things Are Not: Crime Preventers and the 2016 Ugandan Elections." Journal of Eastern African Studies 10(4): 693-712.

- 2017. "Local Security and the (Un)Making of Public Authority in Gulu, Northern Uganda." African Affairs 116(462): 39-59.

- 2021. Arbitrary States: Social Control and Modern Authoritarianism in Museveni's Uganda. New York: Oxford University Press.

Tilly, Charles. 1992. Coercion, Capital, and European States. Cambridge: Basil Blackwell.

Tugal, Cihan. 2017. "The Decline of the Monopoly of Legitimate Violence and the Return of Non-State Warriors." In The Transformation of Citizenship. Vol. 3, Struggle, Resistance and Violence, ed. Juergen Mackert and Bryan S. Turner, 77-92. London: Routledge.

Verma, Cecilie Lanken. 2012. "Guns and Tricks: State Becoming and Political Subjectivity in War-Torn Northern Uganda." Department of Anthropology, Denmark: University of Copenhagen.

Volkov, Vadim. 2002. Violent Entrepreneurs: The Use of Force in the Making of Russian Capitalism. Ithaca, NY: Cornell University Press.

Willis, Graham Denyer. 2015. The Killing Consensus: Police, Organized Crime, and the Regulation of Life and Death in Urban Brazil. Berkeley: University of California Press. 